\title{
PHYSIOLOGICAL PERFORMANCE OF MAIZE (ZEA MAYS L.) UNDER STRESS CONDITIONS OF WATER DEFICIT AND HIGH TEMPERATURE
}

\author{
HAMA, B. M. - MOHAMMED, A. A." \\ Crop Science Department, College of Agricultural Sciences, University of Sulaimani \\ Sulaimani, Kurdistan Region, Iraq \\ (e-mail: bekhal.mustafa@univsul.edu.iq; phone: +964-770-190-0487) \\ *Corresponding author \\ e-mail: aram.muhammed@univsul.edu.iq; phone: +964-770-157-6760 \\ (Received 10 $0^{\text {th }}$ Oct 2018; accepted 29 $9^{\text {th }}$ Nov 2018)
}

\begin{abstract}
The effect of water deficit is usually consistent with the influence of high temperature. In order to evaluate each of the two factors on the physiological performance of six maize (Zea mays L.) hybrids independently, two different experiments have been conducted in the field and the greenhouse. Physiological processes in different vegetative growth stages V10, V14, VT and reproductive growth stage R3 were studied. Photosynthetic rate $(P n)$, transpiration rate $(E)$, and stomatal conductance $(g s)$ as well as specific leaf area (SLA) were examined. Four different water levels were used, while $\mathrm{I}_{1}$ was well irrigated, on the other levels water deficit was created, in $\mathrm{I}_{2}$ in the vegetative growth period, in $\mathrm{I}_{3}$ in the reproductive growth period and in $\mathrm{I}_{4}$ at both vegetative and reproductive periods. The rate of photosynthesis of all six hybrids was increased from V10 to R3 under the effect of $\mathrm{I}_{1}$, while variations in other physiological performance were correlated with water levels and also with the tolerance potential of maize hybrids. The influence of water deficit treatments combined with the effect of high temperature limited the efficiency of physiological traits especially photosynthesis. The consistency between leaf area and the amount of dry matter that partitioned to the leaves was behaved for maintaining the photosynthetic area under stress condition. The greatest change in the rate of the physiological traits of all hybrids occurred with raising the temperature from $\mathrm{T}_{1}$ to $\mathrm{T}_{4}$ in the greenhouse.
\end{abstract}

Keywords: growth response, drought stress, heat stress, corn, irrigation levels

\section{Introduction}

Although the maize crop is classified as a C4-plant the rate of development and productivity are profoundly influenced by drought stress and high temperature, especially in certain stages of crop growth (Brandner and Salvucci, 2002; Tester and Bacic, 2005). The crop productivity in arid and semiarid regions is limited by both high temperature and drought during season growth (Dalirie et al., 2010). All physiological processes are affected by severe environmental factors, and because these processes contribute significantly to the source of the provision of growth requirements, there will be a decrease in the biomass accumulation and the process of seed formation and production (Yang and Zhang, 2006; Prasad et al., 2008; Barnabas et al., 2008; Efeoğlu, 2009; Hatfield and Prueger, 2015).

Specific leaf area is an important factor in the estimation of canopy photosynthesis in crop growth and development, where competition between the source and the sinks will occur. Generally, a higher SLA and a high assimilation rate per unit leaf mass seems to be the most important for achieving fast growth. A negative relationship between SLA and plant photosynthesis was found for a set of genotypes from tropical and temperate sources that were early sown in the field due to environmental or genetic influences (Hund et al., 2005). 
Temperature is one of the most important environmental factors influencing mitochondrial respiration. Respiration exponentially increases with increasing temperatures from $30-35$ or $40^{\circ} \mathrm{C}$, reaching a plateau at $40-50{ }^{\circ} \mathrm{C}$ (Prasad et al., 2008). At a temperature above $40{ }^{\circ} \mathrm{C}$ the enzymes that carry out photosynthesis lose their shape and functionality, and the photosynthetic rate declines rapidly. Ben-Asher et al. (2008) revealed a gradual decline of about $1 P n$ unit per $1{ }^{\circ} \mathrm{C}$ increase in temperature, while the highest temperature treatment descended $P n$ 50-60\%. The transpiration rate was increased from 0.25 and $0.36 \mathrm{~mm} \mathrm{~h}^{-1}$ to 0.36 and $0.54 \mathrm{~mm} \mathrm{~h}^{-1}$ under the influence of high temperature.

Drought stress in maize led to a significant decline in net photosynthesis (33.22\%), transpiration rate $(37.84 \%)$, stomatal conductance $(25.54 \%)$, water use efficiency (50.87\%), as compared to well water control (Anjum et al., 2011; Allen and Ort, 2001). Effect of water shortage during different growing stages of maize sustained different extent impact on biomass accumulation, partitioning and kernel yield (Mi et al., 2018). It was reported that drought usually leads to a reduction of important photosynthetic pigments, and deterioration in the photosynthetic apparatus especially the photosystem II reaction centre (Zhang et al., 2013). To prevent excessive water loss and physiological disadvantages, plants regulate transpiration by adjusting the stomatal conductance (Chaves et al., 2002). Crops are generally more sensitive to water deficit and heat stress during reproductive stages of development (Iings et al., 2013). The physiological responses of plants to effect of drought and heat stress, create a strong relationship between the plant water status and temperature, thus making it very hard to separate the contributions of heat and drought stress under field conditions, the impacts of water deficit and heat stress on the processes of crop plant photosynthesis either through the regulation by stomatal closure or decreasing flow of $\mathrm{CO}_{2}$ into mesophyll tissue (Prasad et al., 2008). The interrelations between SLA and photosynthesis also can be helpful in clarifying differences between photosynthetic rates with different expression dry weight or area bases.

The objective of the study was an investigation of the effect of water deficit and heat stress in combination on the physiological processes $P n, E$, and $g s$ and their impacts on growth performance of a set of maize hybrids under the field condition, where there is water deficit and high temperature and independently in the greenhouse where the only heat stress condition is present.

\section{Materials and methods}

The research was conducted in the field and greenhouse of college of Agricultural Sciences\University of SulaimanilSulaimanilKRG-Iraq (35 $34^{\circ} 19^{\prime \prime} \mathrm{N} 45^{\circ} 22$ ' $1.6^{\prime \prime} \mathrm{E}$ with altitude of 754 m.a.s.l), during the summer season of 2016 and the spring season of 2017 in order to evaluate growth and development of six maize hybrids through studying of some of the physiological traits under the effect of water deficit and high temperature in the field and only heat stress condition in the green house, the map of the study site is demonstrated in Figure 1. A field experiment was conducted in growth condition with the seasonal mean temperature shown in Table 1, and only high temperature stress $\left(30,35,40\right.$, and $\left.45^{\circ} \mathrm{C}\right)$ as $\left(\mathrm{T}_{1}, \mathrm{~T}_{2}, \mathrm{~T}_{3}\right.$, and $\left.\mathrm{T}_{4}\right)$ in the greenhouse during the growth stages pre-silking and post silking. Six maize hybrids \{Medium 791 $\left(\mathrm{H}_{1}\right)$, Cantabpis $\left(\mathrm{H}_{2}\right)$, Btaris $\left(\mathrm{H}_{3}\right)$, Fijr 260( $\left.\mathrm{H}_{4}\right)$, Es-SOLITO 635(H $\left.\mathrm{H}_{5}\right)$ and Dhqan $\left.\left(\mathrm{H}_{6}\right)\right\}$ were seeded. 


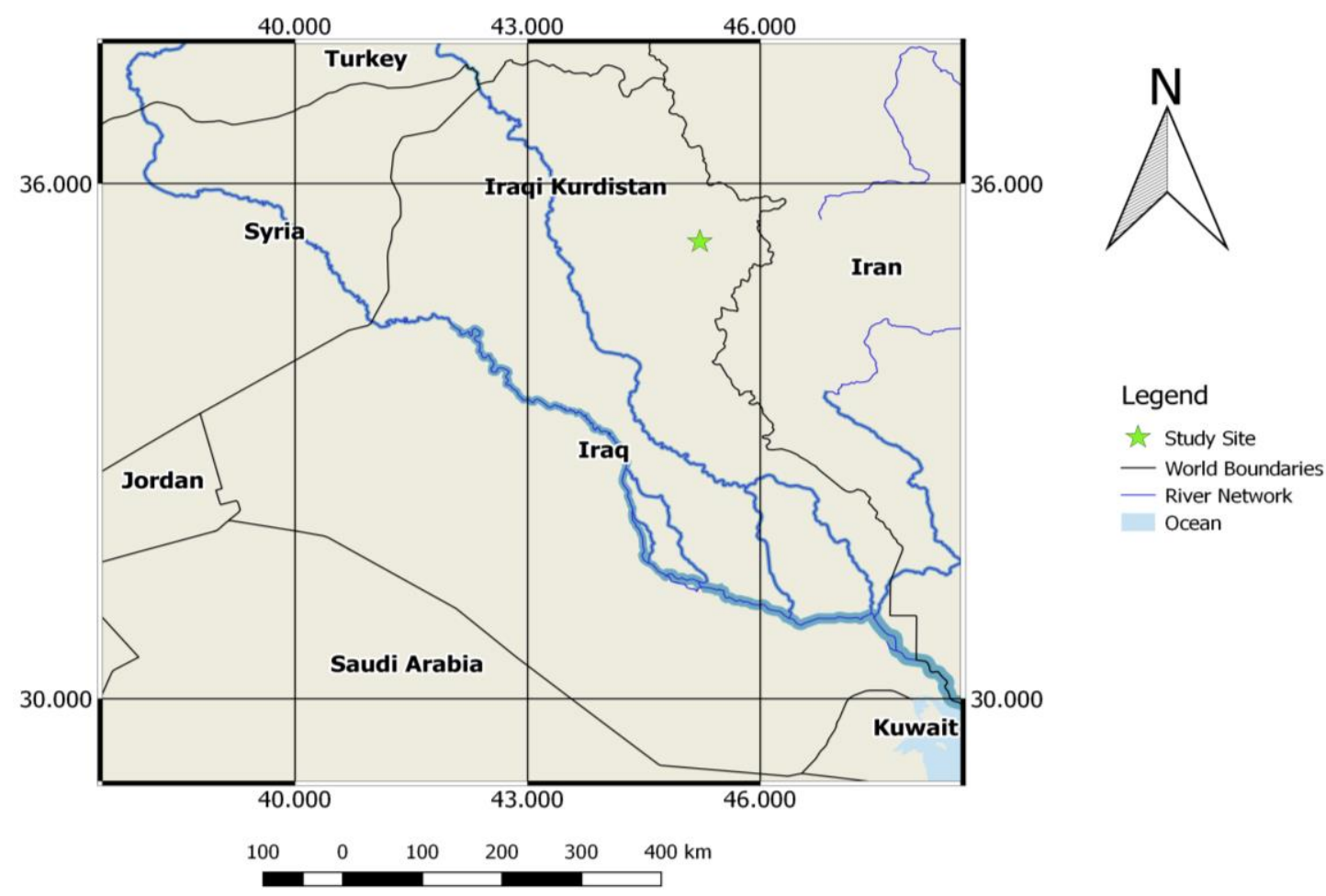

Figure 1. Map of the study site

Table 1. Some meteorological data of the growth season period from July to November, 2016

\begin{tabular}{c|c|c|c|c|c|c}
\hline \multirow{2}{*}{$\begin{array}{c}\text { Growth season } \\
\text { period (month) }\end{array}$} & \multirow{2}{*}{ Precipitation } & \multicolumn{2}{|c|}{ Air temp. ${ }^{\circ} \mathbf{C}$} & \multicolumn{2}{c|}{ Relative humidity \% } & \multirow{2}{*}{ ETo } \\
\cline { 3 - 6 } & & $\mathbf{A T}_{\max }$ & $\mathbf{A T}_{\min }$ & $\mathbf{R H}_{\max }$ & $\mathbf{R H}_{\mathbf{m i n}}$ & \\
\hline July & 0 & 43.5 & 35.4 & 35.8 & 22.9 & 7.9 \\
August & 0 & 45.4 & 37.2 & 31.6 & 20.4 & 7.6 \\
September & 0 & 38.3 & 29.8 & 42 & 26.2 & 6.04 \\
October & 0.1 & 31 & 22.8 & 45.3 & 28.5 & 4.24 \\
November & 0.1 & 23 & 15.1 & 46.9 & 31.2 & 2.87 \\
\hline
\end{tabular}

\section{Field experiment}

The field experiment was laid out as a split plot design with three replicates, the treatments were arranged in which water deficit levels will be in the main plots and the six hybrids were randomly distributed within sub-plots, the plot size was $(4 \times 10.2) \mathrm{m}$. Four irrigation treatments were applied during the growing season, which were well irrigation $\left(\mathrm{I}_{1}\right)$, deficit irrigation during the vegetative period $\left(\mathrm{I}_{2}\right)$, water deficit during reproductive period $\left(\mathrm{I}_{3}\right)$, and water deficit during both of vegetative and reproductive growth periods $\left(\mathrm{I}_{4}\right)$, water deficit was arranged by breaking one irrigation between each two irrigations. Thermal gravimetric method was used to evaluate accurate availability between field capacity and temporary wilting point to prevent the occurrence of moisture stress in the canopy, so there was no uniformity in the irrigation intervals due to crop requirement and air temperature that directly affected soil moisture content and 
reference evapotranspiration (ETo). The soil available water was determined after calculating the soil water content at field capacity (F.C -33) and wilting point (W.P $1500 \mathrm{kpa})$ from the models proposed by Karim (1999, Eqs. 1 and 2):

$$
\begin{aligned}
& \text { F.C }=13.28+0.397(\text { clay } \%) \\
& \text { P.W.P }=4.57+0.35(\text { clay } \%)
\end{aligned}
$$

Where:

F.C $=$ Soil water content at $(-33 \mathrm{kpa})$.

P.W.P = Soil water content at $(-1500 \mathrm{kpa})$

The irrigation (across the growing season) was applied when the soil moisture content became around $20 \%$ to raise the moisture content of the soil to field capacity (30.54\%) (Table 2).

\begin{tabular}{|c|c|c|c|c|c|c|c|}
\hline $\begin{array}{l}\text { Growth } \\
\text { stages }\end{array}$ & $\begin{array}{c}\text { Irrigation } \\
\text { levels }\end{array}$ & $\mathbf{T}_{\min }$ & $\mathbf{T}_{\max }$ & $\mathbf{T}_{\text {mean }}$ & ET & $\mathbf{K}_{\mathbf{c}}$ & $\mathbf{E T}_{\mathbf{c}}$ \\
\hline \multirow{4}{*}{$\begin{array}{l}\text { Initial stage } \\
\text { (28 days) }\end{array}$} & $\mathrm{I}_{1}$ & \multirow{4}{*}{35.6} & \multirow{4}{*}{43.63} & \multirow{4}{*}{39.615} & \multirow{4}{*}{8.39} & \multirow{4}{*}{0.7} & \multirow{4}{*}{5.873} \\
\hline & $\mathrm{I}_{2}$ & & & & & & \\
\hline & $I_{3}$ & & & & & & \\
\hline & $\mathrm{I}_{4}$ & & & & & & \\
\hline \multirow{4}{*}{$\begin{array}{c}\text { Rapid } \\
\text { growth stage } \\
\text { (46 days) }\end{array}$} & $\mathrm{I}_{1}$ & \multirow{4}{*}{35.62} & \multirow{4}{*}{43.88} & \multirow{4}{*}{39.75} & \multirow{4}{*}{7.62} & \multirow{4}{*}{1.2} & \multirow{4}{*}{9.144} \\
\hline & $\mathrm{I}_{2}$ & & & & & & \\
\hline & $\mathrm{I}_{3}$ & & & & & & \\
\hline & $\mathrm{I}_{4}$ & & & & & & \\
\hline \multirow{4}{*}{$\begin{array}{l}\text { Mid-season } \\
\text { stage } \\
\text { (45 days) }\end{array}$} & $\mathrm{I}_{1}$ & \multirow{4}{*}{24.72} & \multirow{4}{*}{33.24} & \multirow{4}{*}{28.98} & \multirow{4}{*}{5.65} & \multirow{4}{*}{1.2} & \multirow{4}{*}{6.78} \\
\hline & $\mathrm{I}_{2}$ & & & & & & \\
\hline & $\mathrm{I}_{3}$ & & & & & & \\
\hline & $\mathrm{I}_{4}$ & & & & & & \\
\hline \multirow{4}{*}{$\begin{array}{l}\text { Late-season } \\
\text { stage } \\
\text { (15 days) }\end{array}$} & $\mathrm{I}_{1}$ & \multirow{4}{*}{17.34} & \multirow{4}{*}{26.13} & \multirow{4}{*}{21.74} & \multirow{4}{*}{4.14} & \multirow{4}{*}{0.6} & \multirow{4}{*}{2.484} \\
\hline & $\mathrm{I}_{2}$ & & & & & & \\
\hline & $\mathrm{I}_{3}$ & & & & & & \\
\hline & $\mathrm{I}_{4}$ & & & & & & \\
\hline
\end{tabular}

Table 2. ETc (amount of applied water) for $I_{1}, I_{2}, I_{3}$ and $I_{4}$ during growing season

The crop was seeded on July 04, 2016, with row spacing of $0.7 \mathrm{~m}$ and $0.25 \mathrm{~m}$ between plants within a row. In order to prevent the lateral spread of water plots a distance of $2 \mathrm{~m}$ between plots was left bare. All of phosphorus fertilizer was applied before sowing time at the rate of $200 \mathrm{~kg} \mathrm{ha}^{-1}$, while the nitrogen fertilizer, $200 \mathrm{~kg} \mathrm{ha}^{-1}$ as urea in $46 \%$ was applied by two doses, at seedling stage and at tasseling. All other agricultural processes were done as required.

The photosynthesis rate $(P n) \mu \mathrm{mol} \mathrm{m} \mathrm{s}^{-2},(E) \mathrm{mmol} \mathrm{m}^{-2} \mathrm{~s}^{-1}$, and $(g s) \mathrm{mmol} \mathrm{m}^{-2} \mathrm{~s}^{-1}$, were measured for three different plants, six leaves of each plant were selected from most upper levels of the plants, the physiological parameters were measured at vegetative growth stages (10 leaves) V10 (14 leaves) V14 (tasseling) VT, and reproductive growth stage (around silking) R3 using a portable computerized LCA-4 
instrument. In addition the leaf area plant $^{-1}$ was measured according to the equation $\{$ Leaf length $(\mathrm{cm}) \times$ Leaf width $(\mathrm{cm}) \times 0.74\}$, the rate of dry matter accumulation and its partitioning to shoot along the season was measured using three different destructive samples (include shoot or plant parts above the soil surface), samples were divided into different parts of the shoot (leaves and stem). Fresh weight of each part was taken and then oven dried till complete dryness at $70{ }^{\circ} \mathrm{C}$ and then waited. For calculating the specific leaf area (SLA) Equation 3 was used (Vile et al., 2005):

$$
\text { Specific Leaf Area }=\frac{\text { Leaf area } / \text { Plant }}{\text { Leaf Weight } / \text { Plant }}(\mathrm{cm} / \mathrm{g})
$$

\section{Greenhouse experiment}

The experiment was carried out in a greenhouse, for evaluating the physiological response of same six maize hybrids to the high temperature stress only, while the irrigation was done as required, in a greenhouse in the College of Agricultural Sciences during the period 01 March to the end of Jun in 2017 with Factorial Complete Randomized Design $(C R D)$ with 3 replications in metal containers $(0.7 \times 3 \times 0.5) \mathrm{m}$, the used soil was brought from the field experiment of Qlyasan. The greenhouse was divided into two parts by using the insulating section for separating the stress part of experiment from control part that thermally controlled between 25 and $27.5^{\circ} \mathrm{C}$, using Temperature and Humidity data logger, while in the second part temperature stress condition was created at two different growth stages pre-silking and post silking by raising the temperature to $30,35,40$, and $45^{\circ} \mathrm{C}$ gradually from $27.5^{\circ} \mathrm{C}$ by raising $2.5^{\circ} \mathrm{C}$ every $2 \mathrm{~h}$ from $6.00 \mathrm{AM}$ to $8.00 \mathrm{PM}$ in order to determine the physiological response under raised temperatures. Scientific illuminators were used for controlling the illumination inside the greenhouse. Seeds of maize hybrids were sown on 01 of March in metal containers in rows with $0.60 \mathrm{~m}$ distance between rows and $0.25 \mathrm{~cm}$ within plants. Fertilization and all agricultural processes were performed as required. A portable computerized LCA- 4 instrument was used for measuring the Physiological traits $(P n) \mu \mathrm{mol} \mathrm{m} \mathrm{m}^{-2} \mathrm{~s}^{-1},(E) \mathrm{mmol} \mathrm{m}^{-2} \mathrm{~s}^{-1}$, and $(g s) \mathrm{mmol} \mathrm{m}^{-2} \mathrm{~s}^{-1}$, at the growth stage post-silking for maize hybrids in both conditions. The data from the two experiments were statistically analyzed according to the JMP pro13, XLSTAT 2016, respectively, and the significant differences of the treatment means were compared with an LSD test at $<0.05$ (Steel et al., 1997).

\section{Results}

\section{Open field experiment}

\section{Physiological processes}

The process of biomass accumulation is closely related to the performance of physiological processes under the influence of water status and ambient temperature. The significant distinction in the physiological performance of six maize hybrids was noticed under the effect of water deficit stress in different growth stages (Figs. 2, 3, and 4). Increasing photosynthetic rates were observed (Fig. 2) from growth stage (ten leaves) V10 to $R_{3}$ under the effect of full irrigation $\left(I_{1}\right)$ and also third level of irrigation $\left(\mathrm{I}_{3}\right)$ in vegetative growth only where there was no shortage of water, and Figure 3 refers to a linear decline of transpiration rate with the water deficit levels from $\mathrm{I}_{1}$ to $\mathrm{I}_{4}$, while the significant effect of irrigation levels on stomatal conductance was showed in Figure 
4, indicating a close relation to soil moisture content that was provided by different irrigation levels.

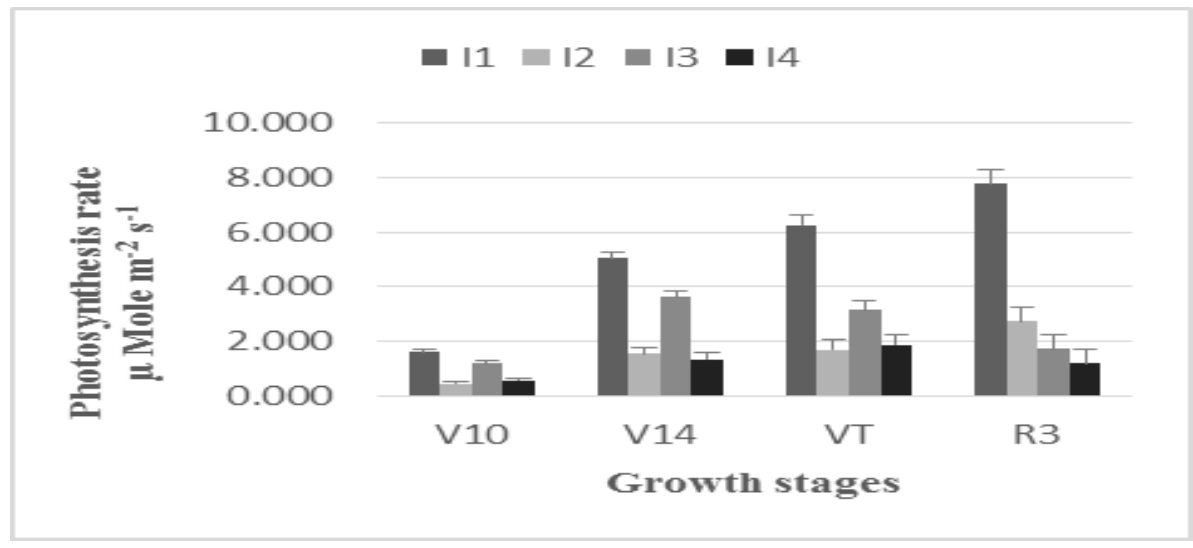

Figure 2. Effect of irrigation levels on the photosynthetic rate (Pn)

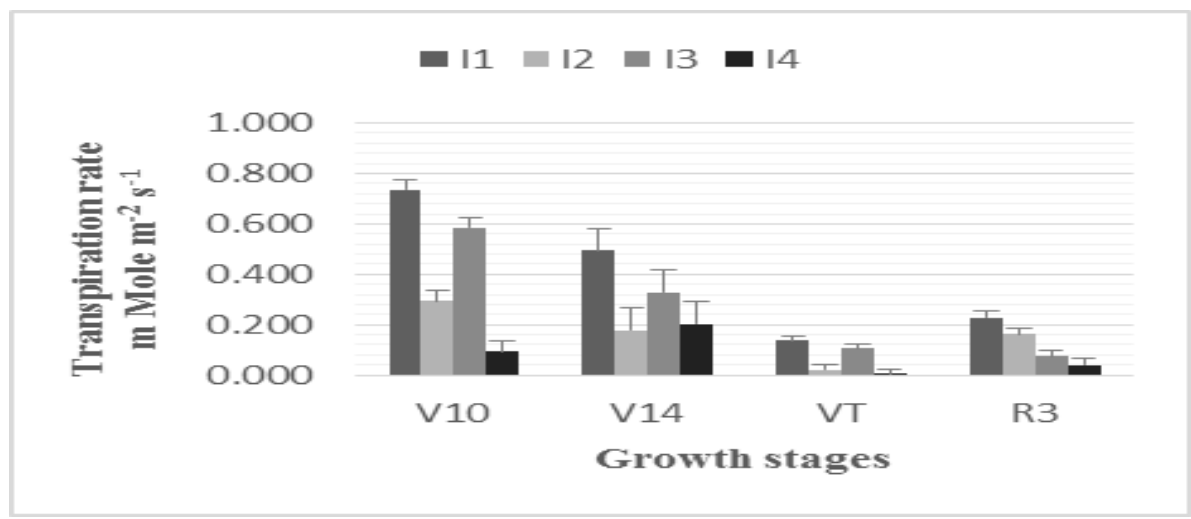

Figure 3. Effect of irrigation levels on the transpiration rate $(E)$

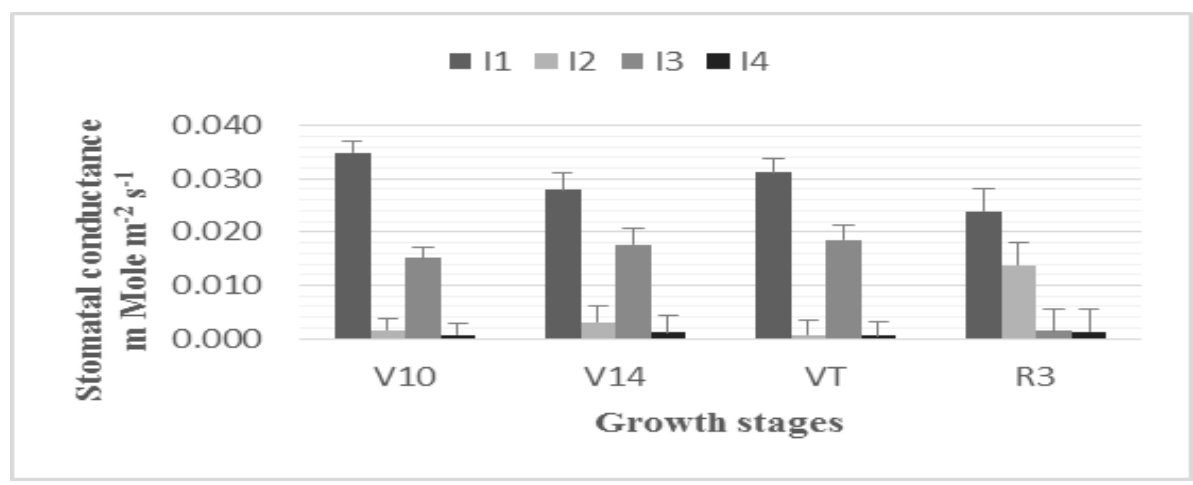

Figure 4. Effect of water deficit levels on the stomatal conductance $(g s)$

There were increases in performance of six maize hybrids in photosynthetic rate across different growth stages from early vegetative stages (V10 and V14) to R3 (Fig. 5), while there was a decline in $E$ from vegetative growth V10 to R3 in which plants were at a knee stage (Fig. 6 and 7) and transpiration rates were undertaken with 
stomatal conductance of all hybrids with few variations, but the obvious decline was at (tasseling) VT that was considered as a growth stage with greater activity of physiological processes that needs a higher quantity of water. There was a consistent relation between the transpiration rate and stomatal conductance for water balancing attainment.

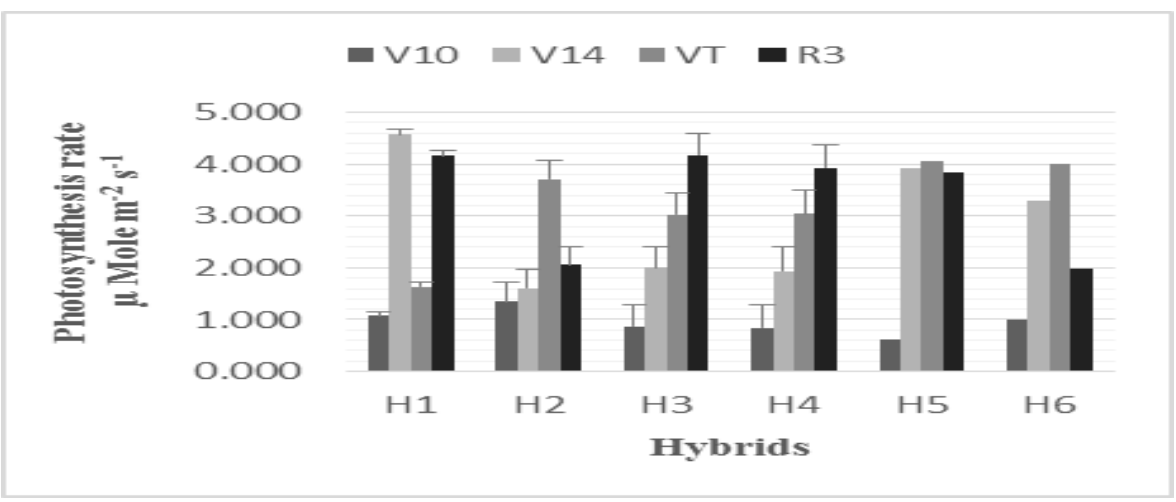

Figure 5. Photosynthetic rate (Pn) of six maize hybrids in different growth stages

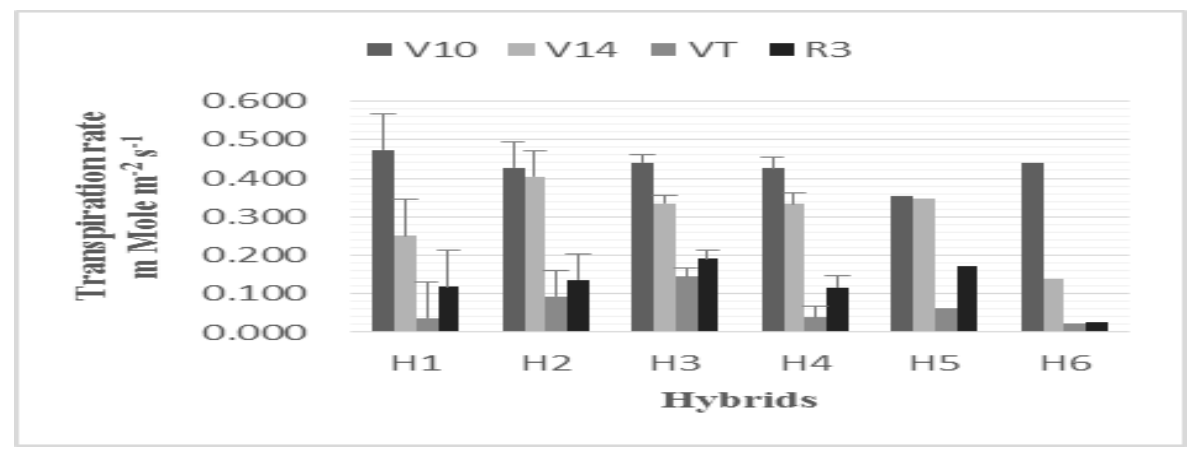

Figure 6. Transpiration rate (E) of six maize hybrids in different growth stages

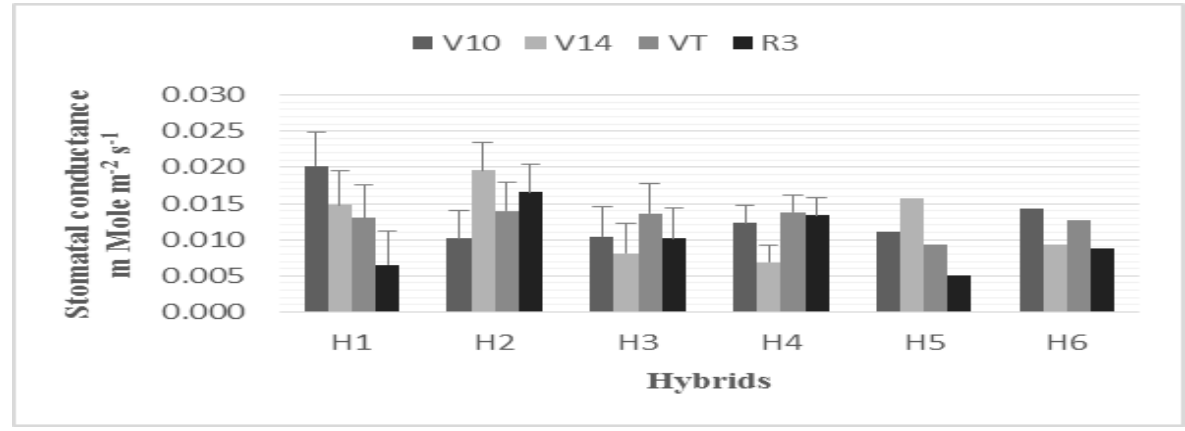

Figure 7. Stomatal conductance ( $g s$ ) of maize Hybrids in different growth stages

\section{Specific leaf area (SLA)}

The results of specific leaf area which is evidently in relation with leaf area and leaf dry weight are displayed in Table 3 and Figure 8, signalling a significant variation of the impact of irrigation levels. There was a general increase in the SLA at all levels of 
water deficit from seedling to the physiological maturity due to plant leaf area development and dry matter accumulation. Plant compatibility between leaf area and the amount of dry matter allocated to the leaves was formed in order to maintain the photosynthetic area under water deficit condition. Maximum SLA was founded to have a significant effect on the 4th level of irrigation from pre-silking stage (31 Aug) to the physiological maturity $\left(180.274,209.338,175.899\right.$, and 202.567) $\left.\mathrm{cm}^{2} \mathrm{~g}^{-1}\right)$, while the superiority of third level at dough stage (Oct.16), $189.373 \mathrm{~cm}^{2} \mathrm{~g}^{-1}$, demonstrated the efficacy of $\mathrm{I}_{3}$ level during the post silking period, and $\mathrm{I}_{4}$ level at different stages of the growth season.

Table 3. Effect of water deficit levels in specific leaf area along the growth season

\begin{tabular}{c|c|c|c|c|c|c|c}
\hline \multirow{2}{*}{$\begin{array}{c}\text { Irrigation } \\
\text { treatments }\end{array}$} & \multicolumn{7}{|c}{ Specific leaf area } \\
\cline { 2 - 8 } & 2-Aug & 16-Aug & 31-Aug & 18-Sep & 2-Oct & 16-Oct & 30-Oct \\
\hline $\mathrm{I}_{1}$ & 85.344 & 112.206 & 137.018 & 132.140 & 115.989 & 102.954 & 158.718 \\
$\mathrm{I}_{2}$ & 138.269 & 133.401 & 134.088 & 184.854 & 145.192 & 165.414 & 186.696 \\
$\mathrm{I}_{3}$ & 95.010 & 119.979 & 141.706 & 150.237 & 152.842 & 189.373 & 194.988 \\
$\mathrm{I}_{4}$ & 136.350 & 124.207 & 180.274 & 209.338 & 175.899 & 171.822 & 202.567 \\
\hline LSD (P $\leq 0.05)$ & N.S & N.S & 31.852 & 51.758 & 22.284 & 41.256 & 25.219 \\
\hline
\end{tabular}

The realization of six maize hybrids in SLA was shown significantly in the postsilking period in which the area of photosynthesis represented by leaf area was accomplished according to the tolerance capability of hybrids to perform the effect of water deficit and high temperature in the open field. As shown in Figure 8 the development of SLA of all hybrids were located during the pre-silking period, showing significant, exceeding of the $\mathrm{H}_{1}$ (medium 791) hybrid in comparison to other hybrids in the V5 and R3. There was a proportional increase in leaf area and the rate of dry matter accumulation per unit leaf area, the light interception and photosynthesis process is directly related to leaf area during this phase of development. The duration post silking showed more fluctuations in SLA according to genetic differences of six maize hybrids and the severity of water deficit levels. There was significant, exceeding of the medium 791 at R3 with $174.141 \mathrm{~cm}^{2} \mathrm{~g}^{-1}$, while the Dhqan hybrid showed significant superiority in the later stages of the reproductive period.

\section{Greenhouse experiment}

Figures 9 and 10 reveal significant decreasing in photosynthesis as temperature raised from $\mathrm{T}_{1}\left(30^{\circ} \mathrm{C}\right)$ to $\mathrm{T}_{4}\left(45^{\circ} \mathrm{C}\right)$, maximum activity of $P n$ was under the effect of $\mathrm{T}_{1}$ which was 27.5 to $30^{\circ} \mathrm{C}$, and then declined rapidly at $\left(35^{\circ} \mathrm{C}\right) \mathrm{T}_{2}$, while there was a gradual decline from $\mathrm{T}_{2}$ to $\mathrm{T}_{3}\left(40^{\circ} \mathrm{C}\right)$ and the lesser rate of $P n$ was at $\left(45^{\circ} \mathrm{C}\right) \mathrm{T}_{4}$. Maize hybrid responses to the effect of rising temperature were significant in $P n$ and $E$ while stomatal conductance showed non-significant response. 


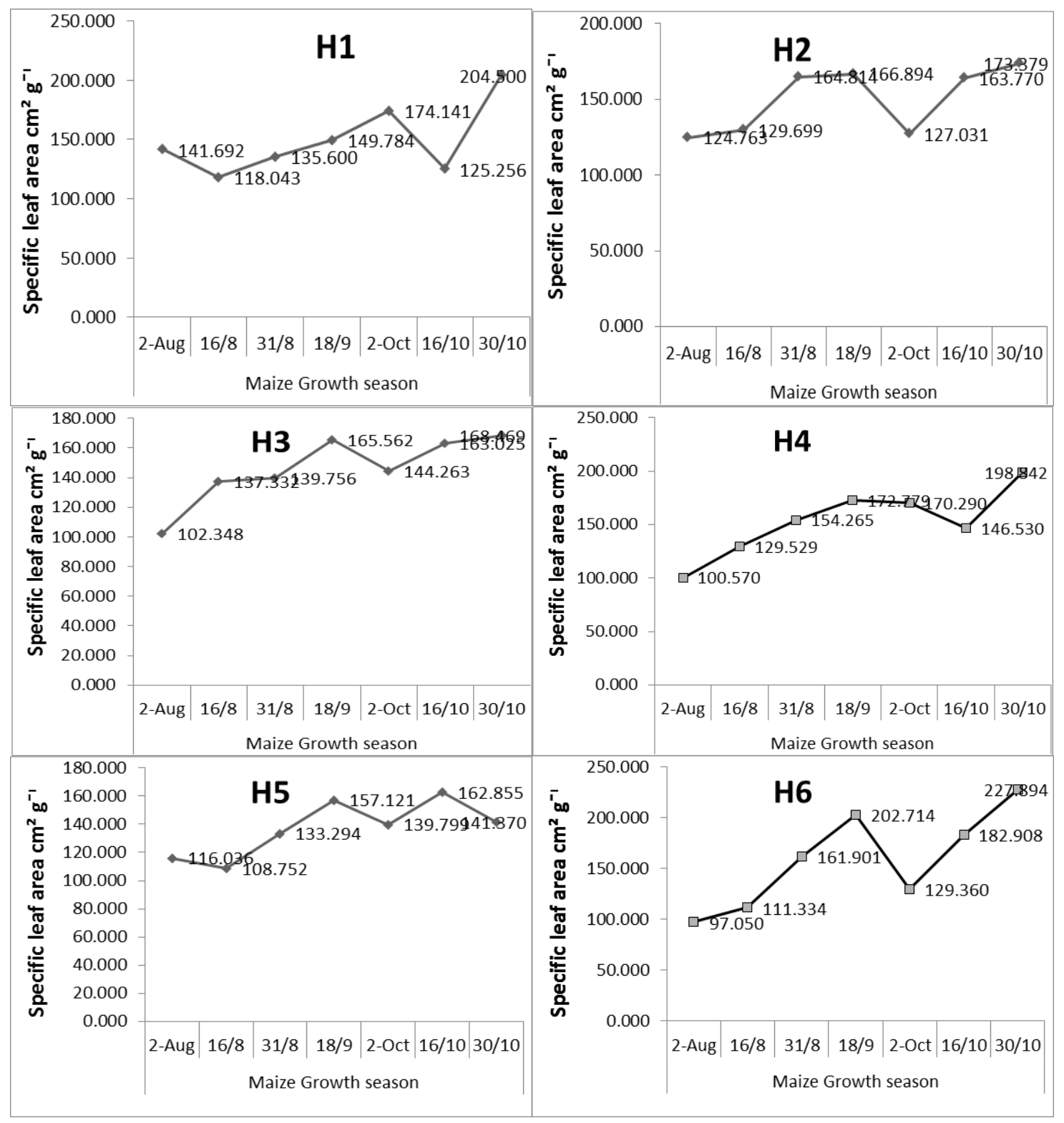

Figure 8. Specific leaf area of six maize hybrids along the growth season

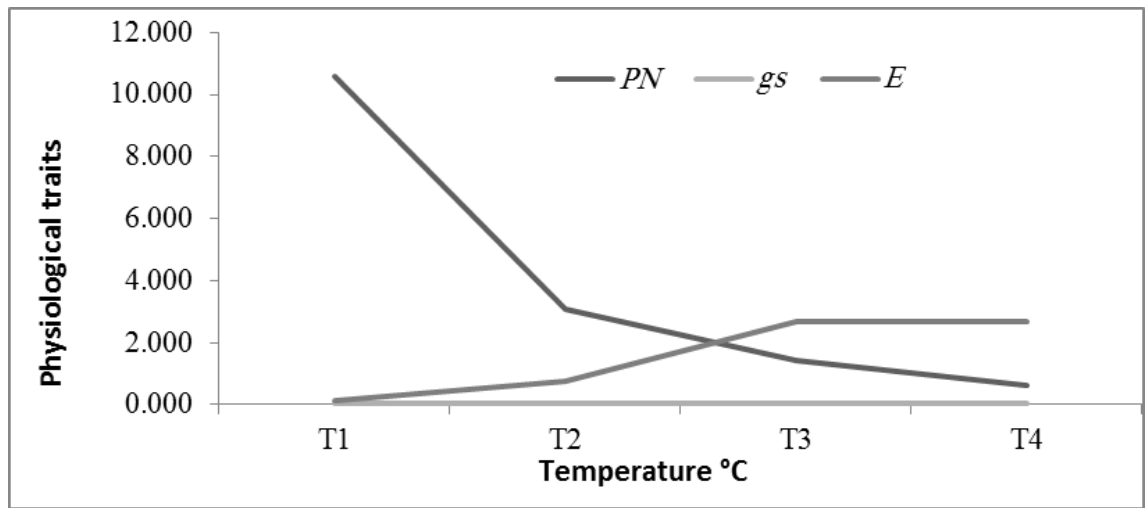

Figure 9. Effect of temperature on physiological traits of maize hybrids in green house 


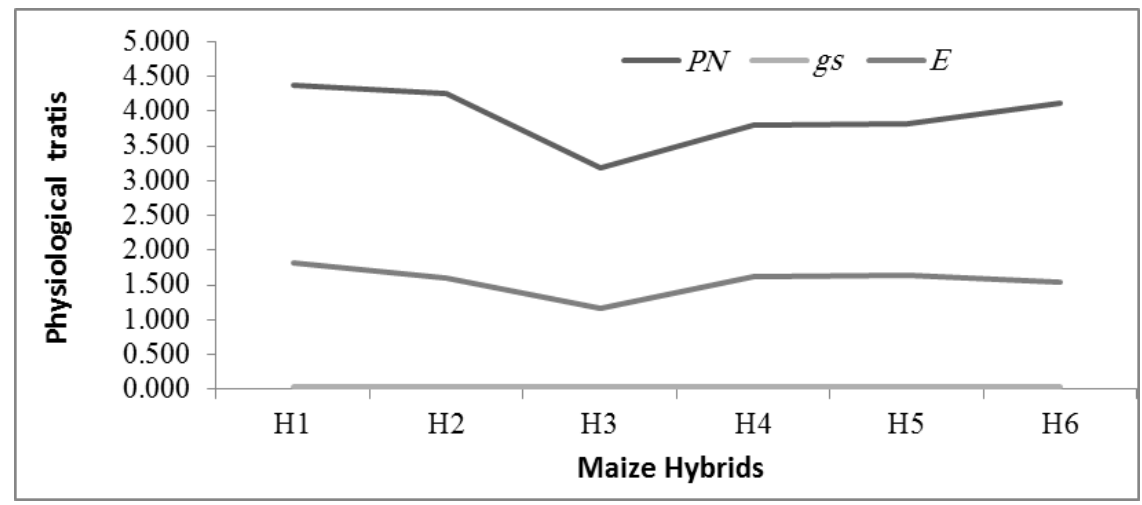

Figure 10. Physiological performances of maize hybrids in green house

The interactions between the effect of temperature levels, and response of maize hybrids demonstrated significant differences in the physiological processes photosynthetic rate, transpiration rate, and stomatal conductance (Figs. 11, 12, and 13), while the highest rate of photosynthetic rate of all hybrids was shown in combination with $T_{1}$, the interactions of maize hybrids and $T_{3}$ and $T_{4}$ showed the maximum rate of transpiration and stomatal conductance.

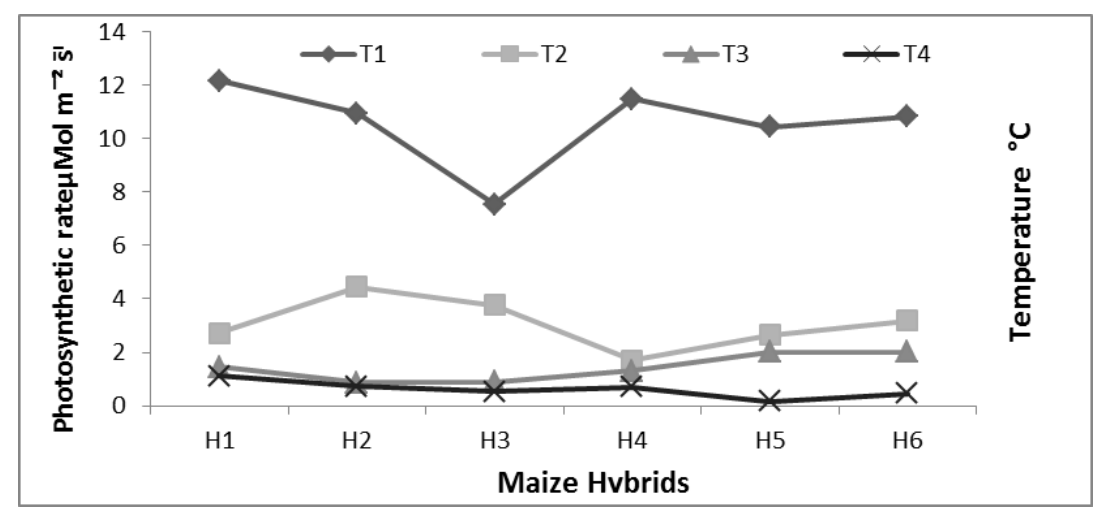

Figure 11. The interactions between maize hybrids and temperature on photosynthetic rate in greenhouse

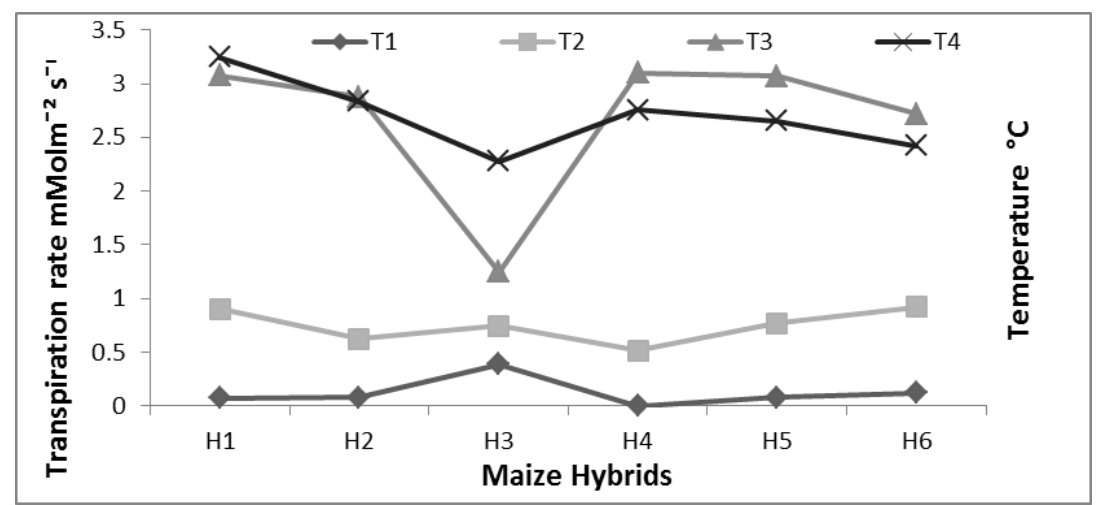

Figure 12. The interactions between maize hybrids and temperature on transpiration rate in the greenhouse 


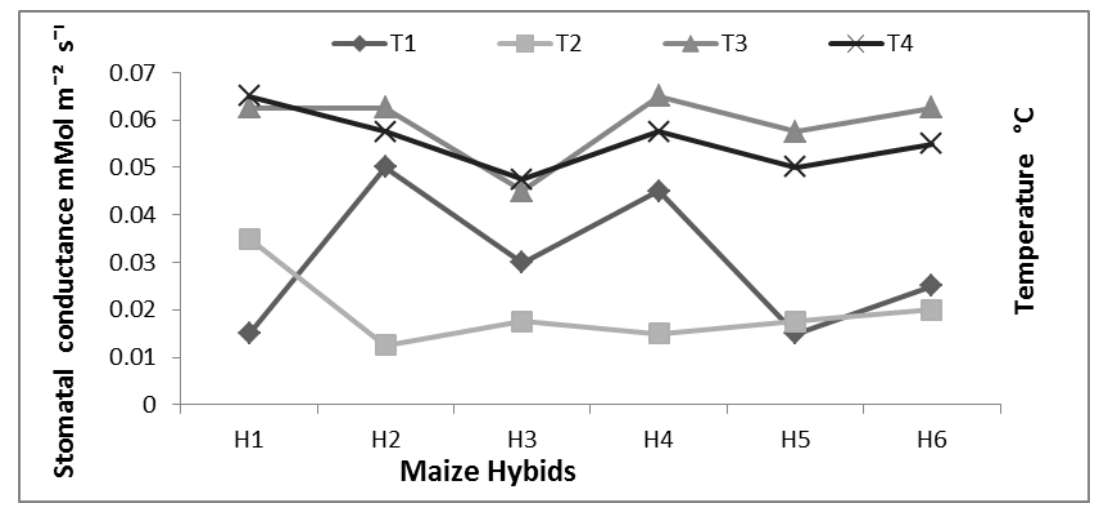

Figure 13. The interactions between maize hybrids and temperature on stomatal conductance in the greenhouse

\section{Comparing the effect of water deficit and heat stress in the field and the single effect} of heat stress in greenhouse on the rate of photosynthesis of maize hybrids

The comparison between performance of maize hybrids was achieved at the reproductive growing period because the susceptibility of crops is generally too high to water deficit and heat stress during the reproductive stages of development. The rate of photosynthesis during the growing period around silking (R3) in the greenhouse under control condition $\left(27.5^{\circ} \mathrm{C}\right)$ revealed the highest activity of $\mathrm{CO}_{2}$ fixation $(7.548-12.18$ $\left.\mu \mathrm{mol} \mathrm{m} \mathrm{m}^{-2} \mathrm{~s}^{-1}\right)$, displayed by hybrids Medium $791\left(\mathrm{H}_{1}\right)$ and Btaris $\left(\mathrm{H}_{3}\right)$ in comparison to stress levels of temperatures $\mathrm{T}_{2}\left(35^{\circ} \mathrm{C}\right), \mathrm{T}_{3}\left(40^{\circ} \mathrm{C}\right)$, and $\mathrm{T}_{4}\left(45^{\circ} \mathrm{C}\right)$ (Fig. 14) the photosynthetic rate of maize hybrids in the open field were higher as well (Fig. 15) in the same growing stage (R3). There was a decline in the $P n$ with rising temperature from $27.5^{\circ} \mathrm{C}$ to $35^{\circ} \mathrm{C}$ in the greenhouse demonstrated by all hybrids, depressing to lower range $\left(1.707-4.46 \mu \mathrm{mol} \mathrm{m} \mathrm{m}^{-2} \mathrm{~s}^{-1}\right)$ was presented by hybrids Fajir $260\left(\mathrm{H}_{4}\right)$ and Cantabpis $\left(\mathrm{H}_{2}\right)$. There was an additional decline in the rate of photosynthesis with rising temperature from $35^{\circ} \mathrm{C}$ to $40{ }^{\circ} \mathrm{C}$ and $45^{\circ} \mathrm{C}$.

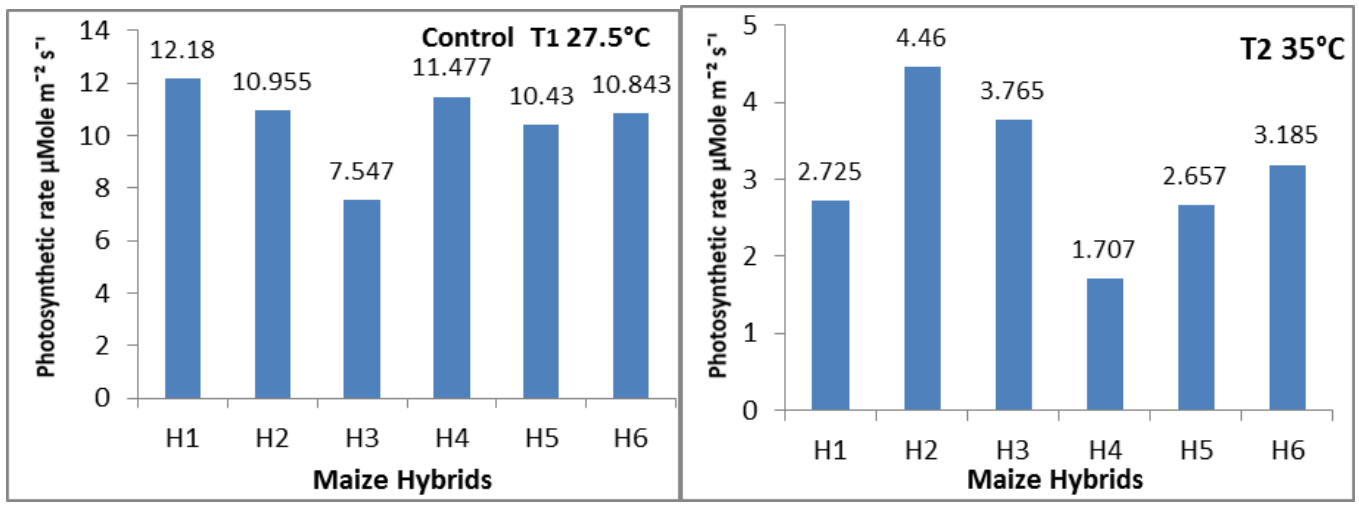




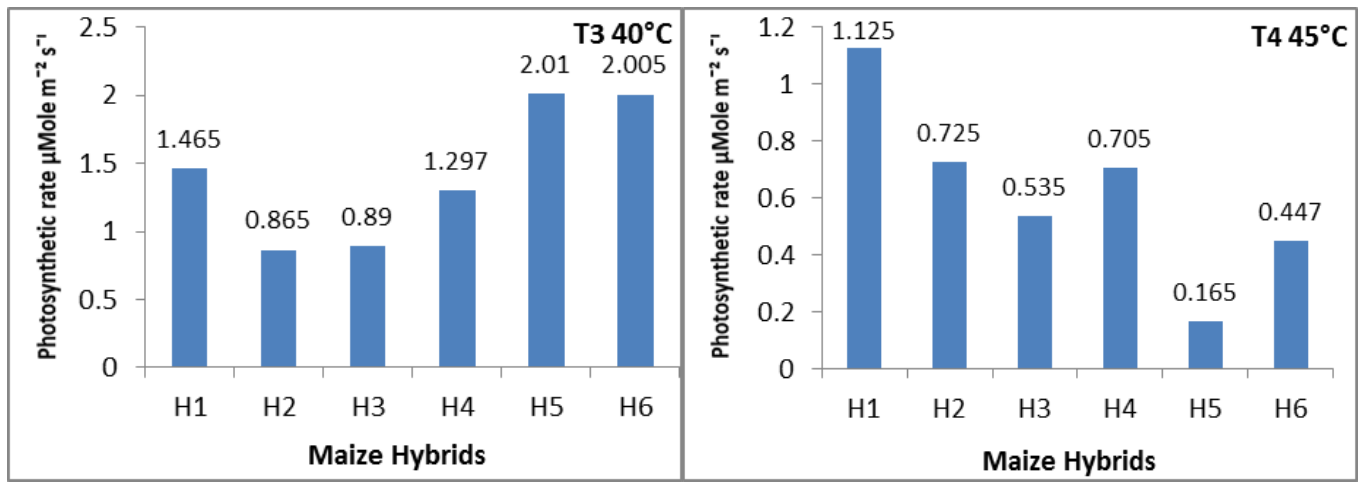

Figure 14. Comparison between Pn rate of maize hybrids in the period around silking (R3) under control condition and heat tress treatments T1, T2, and T3 in greenhouse and open field experiments

The rate of $P n$ of all hybrids under the effect of heat stress at $35{ }^{\circ} \mathrm{C}$ at a growing stage around silking (R3) showed similarity with $P n$ of all hybrids in the same growing stage in the open field (Fig. 15) in which the air temperature was $38.3{ }^{\circ} \mathrm{C}$ (Table 1) and treated with water deficit as well. The similarity between the effect of $\mathrm{T}_{1}\left(35^{\circ} \mathrm{C}\right)$ on the photosynthetic rate of maize hybrids in the growing stage R3 in the greenhouse and the response of the same hybrids in the same growing stage in the open field may be a clear indication of the effective role of heat stress on physiological process $P n$ in comparison to water deficit. There were differences in the performance of maize hybrids in the greenhouse and the open field due to variation in the tolerance and susceptibility potentials of these hybrids.
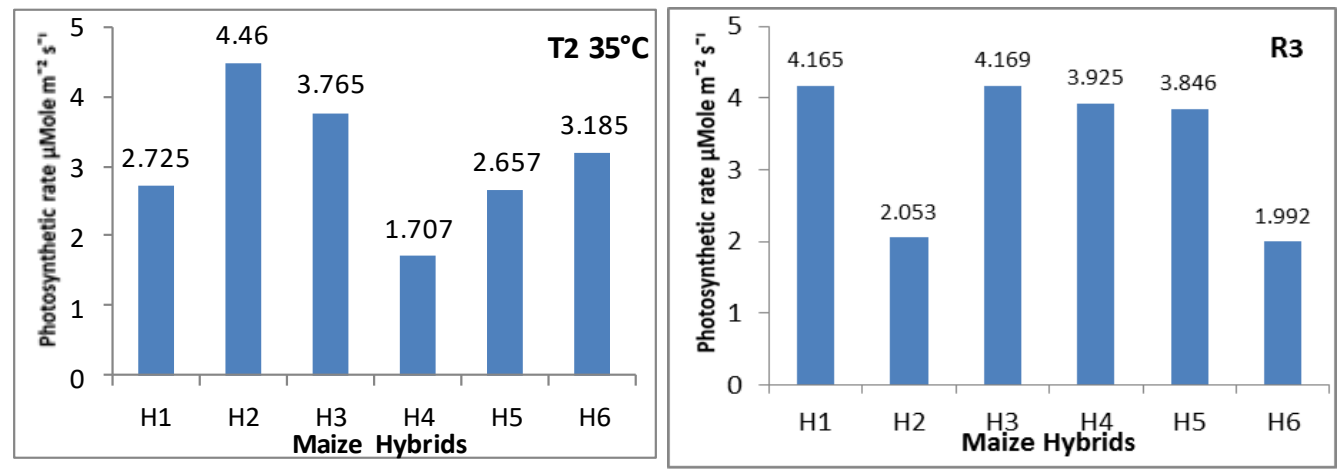

Figure 15. Comparison between Pn rate of maize hybrids in the period around silking (R3) under the effect of $T 2\left(35^{\circ} \mathrm{C}\right)$, in the greenhouse and open field experiments

\section{Discussion}

\section{Open field experiment}

The growth developing from V10 to R3 under the effect of well irrigation and also a third level $\left(\mathrm{I}_{3}\right)$ in vegetative growth only (Fig. 2), resulted from an expansion of plant leaf area, while the light interception is directly related to plant leaf area that is considered as increasing in photosynthetic area, which were smaller under the effect of 
$\mathrm{I}_{2}$ and $\mathrm{I}_{4}$ (Kim et al., 2006; Moosavi, 2012; Lukeba et al., 2013). Maximum rate of $E$ was shown under the influence of $\mathrm{I}_{1}$ and declined at $\mathrm{I}_{2}, \mathrm{I}_{3}$, and $\mathrm{I}_{4}$, the higher rates of $E$ was in the vegetative stages V10 and V14. These results are in agreement with Ray et al. (2002), Schmidt et al. (2011), Khayatenazhad and Gholamen (2012), Tardieu (2013), Gholipoor et al. (2013) and Liang et al. (2018). The highest rate of ( $g s$ ) was shown under the effect of $\mathrm{I}_{1}$ in all growth stages and $\mathrm{I}_{3}$ during the vegetative growth stages with no water deficit, according to the irrigation schedule while the minimum performance of $(g s)$ was recorded with $\mathrm{I}_{2}$ at the pre-tasseling (VT) stage and $\mathrm{I}_{4}$ across the growth season due to providing a lesser quantity of the crop water requirement under the effect of this level of irrigation (Jeffery et al., 2002; Yu et al., 2016).

Differences in the rate of photosynthesis of maize hybrids in different growth stages may due to the differentiation and plant development that photosynthesis directly affect the rate of dry matter accumulation (Ding et al., 2007; Zhang et al., 2013) especially during the mid age of plants VT around silking toward physiological maturity in which maximum area of plant leaves was produced with exception of the Dihqan hybrid $\left(\mathrm{H}_{6}\right)$. This shows a decline in the photosynthetic rate in the later period of post-silking which showed the capability of that hybrid for acclimation to the hot climate at that period, in which the daily air temperature rose to $45^{\circ} \mathrm{C}$ that created a condition that can damage photosynthetic pigments and apparatus (Mohammedkhani and Heidari, 2007; Saglam et al., 2014; Ji et al., 2017). The water deficit levels $\mathrm{I}_{2}, \mathrm{I}_{3}$, and $\mathrm{I}_{4}$ limited photosynthesis rate of all hybrids, according to the amount of provided water in different growth stages, and also the genetic tolerance of hybrids to the high air temperature that affected gas exchange in these treatments. The greater influence on the physiological traits was with $\mathrm{I}_{2}$ during the vegetative growth stage and $\mathrm{I}_{3}$ at reproductive growth and the growth season along with the effect of $\mathrm{I}_{4}$. The results were in agreement with Del Blanco et al. (2000) and Samarah et al. (2009). However the abiotic stresses, water deficit and heat are usually influenced under the field condition in combination manner, there was a mitigating effect of lower temperature during the beginning of vegetative growth and the later period of the reproductive stage. The effect of the interactions between irrigation level $\left(\mathrm{I}_{2}\right)$ and hybrids on the rate of transpiration showed a relative increase in V10 due to lower requirement of plants to water because of smaller size of plants and lower air temperature in that period while there were lower rate of $(E)$ at other stages especially at VT in which there was a combination of higher demand of plants to water and higher air temperature. The rate of transpiration was affected by air temperature and physiological resistance of maize hybrids and their adaptation to the low soil water status, similar results were reported by Ray et al. (2002) and Gholipoor et al. (2013). Stomatal conductance $(g s)$ showed a lower rate under the influence of the interactions between $\mathrm{I}_{4}$ level and responses of six maize hybrids, decline in the stomatal conductance and transpiration rate were considered as adaptations to tolerance of plants to dehydration status, in which both stomatal conductance and transpiration rate decrease with a higher water vapor pressure deficit that is resulted under impact of higher air temperature at that period, these results are in line with Bunce (2000), Leakey et al. (2006), Schmidt et al. (2011), Witt et al. (2012) and Kuca and Erekul (2016).

Responses of six maize hybrids to water balance achievement were obviously expressed through the specific leaf area of six maize hybrids in which the leaf characteristics efficiently display the whole plant growth. Figure 8 displays significant, exceeding of the medium $791\left(\mathrm{H}_{1}\right)$ hybrid in SLA in comparison to other hybrids on 
post silking around R3. The differences in the performance of the hybrid $\mathrm{H}_{1}$ and other hybrids depend on the genetic capacity for the accomplishment of the consistency between leaf area and potential accumulation of leaf dry matter, smaller leaf dry weight can be compensated by leaf area expansion. While there was general development of SLA of all hybrids during the period of pre-silking, there was a proportional expansion in leaf area and the rate of dry matter accumulation per unit leaf area. The previous studies resulted negative relationships between leaf biomass and photosynthetic rate (Ninemets et al., 2007) which influences the maintenance of plant growth and qualitative aspects of phenology (Vile et al., 2005). The increase in leaf dry weight from the partitioning of more assimilation rate of the leaves resulted in the longevity and maintenance of photosynthetic rate (Westoby et al., 2002). The light interception and photosynthesis process are directly related to leaf area during this stage of growth and development and susceptibility to adverse environmental conditions during one or more phases or stages of phenological development (Hund et al., 2005).

\section{Greenhouse experiment}

Since the effects of high temperature and water deficit in the field cannot be studied independently, the responses of maize hybrids to the effect of high temperature were studied in the greenhouse. Physiological responses of six maize hybrids were showing significant variation between the control growth condition and the heat stress condition in the greenhouse because high temperature is considered as a major factor that affect the metabolite activity of plants (Shah et al., 2011; Hatfield and Prueger, 2015). The maximum activity of $P n$ was under the effect of $\mathrm{T}_{1}$, and then declined rapidly at $\mathrm{T}_{2}$ with a $29.2 \%$ decrease, but there was gradual decline from $\mathrm{T}_{2}$ to $\mathrm{T}_{3}$. There was an increase in the rate of transpiration with increasing the temperature to $\mathrm{T}_{3}\left(40{ }^{\circ} \mathrm{C}\right)$ The plateau state was reached in the rate of $E$ as the temperature continued rising to $\mathrm{T}_{4}\left(45^{\circ} \mathrm{C}\right)$, increasing in transpiration rate may resulted from the necessity of maize plants to cooler conditions under higher temperature to maintain physiological processes but it reached a plateau level from $T_{3}$ to $T_{4}$ due to water vapor pressure which depend on soil water status and air temperature. These affect the difference between air relative humidity and plant water potential which influnce transpiration rate declining (Ray et al., 2002; Taiz and Zeiger, 2006). The direct relationship between $P n$ and $E$ was shown in response of all maize hybrids except Dihqan hybrid $\left(\mathrm{H}_{6}\right)$, while it maintained higher $P n$ in comparison to Es-SOLITO $635\left(\mathrm{H}_{5}\right)$ but the rate of $E$ was much lower, the potential efficiency of that hybrid may genetically adapted to stress conditions (Leakey et al., 2006; Feng et al., 2014; Obata et al., 2015).

The downhill of the rate of Photosynthesis $(P n)$ with increasing the effect of heat stress resulted in raising the temperature from the control condition $\left(27.5^{\circ} \mathrm{C}\right)$ to $\left(35^{\circ} \mathrm{C}\right)$ $\mathrm{T} 1\left(40{ }^{\circ} \mathrm{C}\right) \mathrm{T}_{2}$, and $\left(45^{\circ} \mathrm{C}\right) \mathrm{T} 3$. The maximum rate of $\mathrm{CO}_{2}$ fixation or photosynthesis displayed by six maize hybrids was under control condition $\left(27.5^{\circ} \mathrm{C}\right)$, which is the optimum extent of temperature for C4-plant photosynthesis (Steven et al., 2002). The premium rate of $P n$ under control condition was impaired with the impact of the higher temperature of $\mathrm{T}_{1}, \mathrm{~T}_{2}$, and $\mathrm{T}_{3}$. The lower average of $P n$ while the temperature raised to $35^{\circ} \mathrm{C}$ demonstrated by all hybrids with discrimination among hybrid responses. There were similar performances of six maize hybrids of photosynthesis averages in the greenhouse and open field during the period around silking (Fig. 15). The Pn rate of greenhouse was under heat stress only while, the influence of the combination of water deficit with heat stress was observed in the open field. The results may lead to a more 
effective identification of stress factors on the rate of photosynthesis, the effects of heat stress on the metabolic processes and photosynthetic apparatus (Sage and Kubien, 2007). Drought stress allows maintaining of the insufficient growth in plants (Avramova et al., 2015).

\section{Conclusions}

The results of the field experiment reveal the direct effect of deficiency of water during the different stages of growth and development of maize. The stress conditions created under the influence of water deficit combined with high temperature more than $40{ }^{\circ} \mathrm{C}$ for a long time, predominately during the period of tasseling and silking. A great reduction was generated in the physiological performance, especially photosynthetic rate, which indirectly impact dry matter accumulation and its partitioning of maize, as well the higher rates of $E$ was in the vegetative stages V10 and V14. The differences in the physiological performance of the maize hybrids depend on the genetic capacity for the accomplishment of the consistency between leaf area and potential accumulation of leaf dry matter, smaller leaf dry weight can compensate by leaf area expansion. The influence of temperature higher than $35^{\circ} \mathrm{C}$ in greenhouse created restriction to the photosynthetic rate of maize hybrids, there were significant decreasing in photosynthesis as temperature raised from $27.5^{\circ} \mathrm{C}\left(\mathrm{T}_{1}\right)$ to $45^{\circ} \mathrm{C}\left(\mathrm{T}_{4}\right)$, maximum activity of $P n$ was under the effect of $\mathrm{T}_{1}$. The relation between $P n$ and $E$ was shown in response of all maize hybrids except Dihqan, while it maintained higher $P n$, the rate of $E$ was much lower. The comparison of the effect of temperature as a single factor in the greenhouse and effect of both water deficit and heat stress in the open field revealed greater effect of temperature on photosynthetic rate at reproductive stage R3. Water provided during reproductive stage around silking R3 may mitigate the deleterious effect of high temperature in the field.

\section{REFERENCES}

[1] Allen, D. J., Ort, D. R. (2001): Impact of chilling temperatures on photosynthesis in warm climate plants. - Trends Plant Sci. 6: 36-42.

[2] Anjum, S. A., Wang, L. C., Farooq, M., Hussain, M., Xue, L. L., Zou, C. M. (2011): Brassinolide application improves the drought tolerance in maize through modulation of enzymatic antioxidants and leaf gas exchange. - Agron. J. \& Crop Sci. 197: 177-185.

[3] Avramova,V., AbdElgawad, H., Zhang, Z., Fotschki, B., Casadevall, R., Vergauwen, L., Knapen, D., Taleisnik, E., Guisez, Y., Asard, H., Beemster, G. T. (2015): Drought Induces Distinct Growth Response, Protection, and Recovery Mechanisms in the Maize Leaf Growth Zone. - Plant Physiology 169:1382-1396.

[4] Barnabas, B., Jageri, K., Feher, A. (2008): The effect of drought and heat stress on reproductive processes in cereals. - Plant Cell Environ. 31: 11-38.

[5] Ben-Asher, J., Garcia, A., Hoogenboom, G. (2008): Effect of high temperature on photosynthesis and transpiration of sweet corn (Zea mays L. var. rugosa). Photosynthetica 46(4): 595-603.

[6] Brandner, S. J. C., Salvucci, M. E. (2002): Sensitivity of Photosynthesis in a C4 Plant, Maize, to Heat Stress. - Plant Physiol. 129: 1773-1780.

[7] Bunce, A. J. (2000): Responses of stomatal conductance to light, humidity and temperature in winter wheat and barley grown at three concentrations of carbon dioxide in the field. - Glob Change Boil. 4: 371-382. 
[8] Chaves, M. M., Pereira, J. S., Maroco, J., Rodrigues, M. L., Ricardo, C. P. P., Osório, M. L., Carvalho, I., Faria, T., Pinheiro, C. (2002): How plants cope with water stress in the field? Photosynthesis and growth. - Ann. Bot. 89: 907-16.

[9] Dalirie, M., Sharifi, R. S., Farzanea, S. (2010): Evaluation of yield, dry matter accumulation and leaf area index in wheat genotypes as affected by terminal drought stress. - Not. Bot. Hort. Agrobot. Cluj 38(1): 182-186.

[10] Del Blanco, I. A., Rajaram, S., Kronstad, W. E., Reynolds, M. P. (2000): Physiological performance of synthetic hexaploid wheat-derived populations. - Crop Sci. 40: 12571263.

[11] Ding, L., Wang, K. J., Jiang, G. M., Liu, M. Z., Gao, L. (2007): Photosynthetic rate and yield formation in different maize hybrids. - Biol Plantarum. 51: 165-168.

[12] Efeoğlu, B. Y., Ekmekçi, N., Çiçek, N. (2009): Physiological responses of three maize cultivars to drought stress and recovery. - S. Afr. J. Bot. 75: 34-42.

[13] Feng, B. Liu, P., Li, G., Dong, S. T., Wang, F. H., Kong, L. A., Zhang, J. W. (2014): Effect of heat stress on the photosynthetic characteristics in flag leaves at the grain-filling stage of different heat-resistant winter wheat varieties. - Agron. J. \& Crop Sci. 200: 143155.

[14] Gholipoor, M., Sinclair, T. R., Raza, M. A. S., Löffler, C., Cooper, M., Messina, C. D. (2013): Maize hybrid variability for transpiration decrease with progressive soil drying. Agron. J. \& Crop Sci. 199: 23-29.

[15] Hatfield, J. L., Prueger, J. H. (2015): Temperature extremes: Effect on plant growth and development. - Weather and Climate Extremes 10: 4-10.

[16] Hund, A., Frascaroli, E., Leipner, J., Jompuk, C., Stamp, P., Fracheboud, Y. (2005): Cold tolerance of the photosynthetic apparatus: pleiotropic relationship between photosynthetic performance and specific leaf area of maize seedlings. - Molecular Breeding 16: 321331.

[17] Ings, J. A., Mur, L. J., Robson, P. R. H., Bosch, M. (2013): Physiological and growth responses to water deficit in the bioenergy crop Miscanthus x giganteus. - Front Plant Sci. 4: 00468.

[18] Jeffery, D., Gesch, R. R., Sinclair, T. R., Allen, L. H., Ray, R. W., Gesch, T. R., Allen, L. (2002): The effect of vapor pressure deficit on maize transpiration response to a drying soil. - Plant Soil. 239: 113-121.

[19] Ji, Y., Zhou, G., Ma, X., Wang, Q., Liu, T. (2017): Variable photosynthetic sensitivity of maize (Zea mays L.) to sunlight and temperature during drought development process. Plant, Soil and Env. 63(11): 505-511.

[20] Karim, T. H. (1999): Models to predict water retention of Iraqi soil. - J. of the Indian Soc. of Soil Sci. 47(1): 16-19.

[21] Khayatnezhad, M., Gholamin, R. (2012): The effect of drought stress on leaf chlorophyll content and stress resistance in maize cultivars (Zea mays). - Afr. J. Microbial. Res. 6: 2844-2848.

[22] Kim, S., Sicher, R. C., Bae, H., Gitz, D. C., Baker, J. T., Timlin, J., Reddy, I. (2006): Canopy photosynthesis, evapotranspiration, leaf nitrogen, and transcription profiles of maize in response to $\mathrm{CO}_{2}$ enrichment. - Global Change Biol. 12: 588-600.

[23] Kuca, Y. O., Erekul, O. (2016): Changes of dry matter, biomass and relative growth rate with different phenological stages of corn. - Agr. \& Agr. Sci. Procedia 10: 67-75.

[24] Leakey, A. D., Uribelarrea, B. M., Ainsworth, E. A., Naidu, S. L., Rogers, A., Ort, D. R., Long, S. P. (2006): Photosynthesis, productivity, and yield of maize are not affected by open-air elevation of $\mathrm{CO}_{2}$ concentration in the absence of drought. - Plant Physio. 140: 779-790.

[25] Liang, Y. P., Gao, Y., Wang, G. S., Si, Z. Y., Shen, X. J., Duan, A. W. (2018): Luxury transpiration of winter wheat and its responses to deficit irrigation in North China Plain. Plant Soil Environ. 64: 361-366. 
[26] Lukeba, J. L., Vumilia, R. K., Nkongolo, K. C. K., Mwabila, M. L., Tsumbu, M. (2013): Growth and leaf area index simulation in maize (Zea mays L.) under small-scale farm conditions in a Sub-Saharan African region. - Am. J. Pl. Sc. 4: 575-583.

[27] Mi, N., Cai, F., Zhang, Y., Ji, R., Zhang, S., Wang, Y. (2018): Differential responses of maize yield to drought at vegetative and reproductive stages. - Plant Soil Environ. 64(6): 260-267.

[28] Mohammedkhani, N., Eidari, R. (2007): Effect of water stress on respiration, photosynthetic pigment and water content in two maize cultivars. - Pak. J. Bot. 10: 40224028.

[29] Moosavi, S. G. (2012): The effect of water defcit stress and nitrogen fertilizer levels on morphology traits, yield and leaf area index in maize. - Pak. J. Bot. 44: 1351-1355.

[30] Ninemets, N. L., Portsmuth, A., Tena, D., Tobiasi, M., Matesanze, S., Valladares, F. (2007): Do we underestimate the importance of leaf size in plant economics disproportional scaling of support costs within the spectrum of leaf physiognomy. Annals of Botany 100: 283-303.

[31] Obata, T., Witt, S., Lisec, J., Palacios-Rojas, N., Florez-Sarasa, I., Yousfi, S., Araus, J. L., Cairns, J. E., Fernie, A. R. (2015): Metabolite profiles of maize leaves in drought, heat, and combined stress field trials reveal the relationship between metabolism and grain yield. - Plant Physio. 169: 2665-2683.

[32] Prasad, P. V. V., Staggenborg, S. A., Ristic, Z. (2008): Impacts of Drought and/or Heat Stress on Physiological, Developmental, Growth, and Yield Processes of Crop Plants. ASA, CSSA, SSSA, Madison, WI.

[33] Ray, J. D., Gesch, R. W., Sinclair, T. R. Allen, L. H. (2002): The effect of vapor pressure deficit on maize transpiration response to a drying soil. - Plant Soil. 239: 113-121.

[34] Saglam, A., Kadioglu, A., Demralay, M., Terzi. R. (2014): Leaf rolling reduces photosynthetic loss in maize under severe drought. - Acta Bot. 73: 315-332.

[35] Samarah, N. H., Alqudah, A. M., Amayreh, J. A., McAndrews, G. M. (2009): The effect of late-terminal drought stress on yield components of four barley cultivars. - Agron. J. Crop Sci. 195: 427-441.

[36] Schmidt, J. J., Blankenship, E. E., Lindquist, J. L. (2011): Corn and Velvetleaf (Abutilon theophrasti) Transpiration in Response to Drying Soil. - Weed Sci. 59: 50-54.

[37] Shah, F., Huang, J., Cui, K., Nie, L., Shah, T., Chen, C., Wang, K. (2011): Impact of high-temperature stress on rice plant and its traits related to tolerance. - J. Agr Sci. 10: 112 .

[38] Steel, R. G. D., Torrie, J. H., Dickey, D. A. (1997): Principles and Procedures of Statistics: A biometrical approach. $3^{\text {rd }}$ ed. - McGraw Hill Book, Co. Inc., New York, pp. 400-428.

[39] Steven, J. C., Michael, E. S. (2002): Sensitivity of photosynthesis in a C4 plant, maize, to heat stress. - Plant Physiology, American Society of Plant Biologists 129: 1773-1780.

[40] Taiz, L., Zeiger, E. (2006): Plant Physiology. 4th ed. - Sinauer Associates, Inc., Sunderland, MA.

[41] Tardieu, F. (2013): Plant response to environmental conditions: assessing potential production, water demand, and negative effects of water deficit. - Front Phys 18: 00017.

[42] Tester, M., Bacic, M. (2005): Abiotic stress tolerance in grasses. From model plants to crop plants. - Plant Physiol 137: 791-793.

[43] Vile, D., Garnier, E., Shipley, B., Laurent, G., Navas, M-L, Roumet C, Lavorel S, Díaz, S., Hodgson, J. G., Lloret, F., Midgley, G. F., Poorter, H., Rutherford, M., C., Wilson, P. J., Wright, I. J. (2005): Specific leaf area and dry matter content estimate thickness in laminar leaves. - Annals of Botany 96: 1129-1136.

[44] Westoby, M., Falster, D. S., Moles, A. T., Vesk, P. A., Wright, I. J. (2002): Plant ecological strategies: some leading dimensions of variation between species. - Annual Review of Ecology and Systematics 33: 125-159. 
[45] Witta, S., Galiciab, L., Liseca, J., Cairnsc, J., Tiessend, A., Arause, J. L. Palacios-Rojasb, N., Ferniea, A. R. (2012): Metabolic and phenotypic responses of greenhouse-grown maize hybrids to experimentally controlled drought stress. - Mol Plant 5: 401-417.

[46] Yang, J. C., Zhang, J. H. (2006): Grain filling of cereals under soil drying. - New Phytol. 169: 223-236.

[47] Yu, C. L., Hui, D., Deng, Q., Wang, J., Reddy, K. C., Denni, S. (2016): Responses of corn physiology and yield to six agricultural practice over three years in middle Tennessee. - Scientific Reports 6: 27504.

[48] Zhang, X., Huang, G., Zhao, Q. (2013): Differences in maize physiological characteristics, nitrogen accumulation, and yield under different cropping patterns and nitrogen levels. - Chil. J. Agr. Res. 74: 326-332. 